\title{
American expansion, Russian threat and active democracy: An institutional perspective on triathlon history
}

\author{
Andrey S. Adelfinsky \\ Bauman Moscow State Technical University, Russia, Moscow, e-mail: adelfi@mail.ru
}

Citation: Adelfinsky A.S. (2021). American expansion, Russian threat and active democracy: An institutional perspective on triathlon history. Terra Economicus 19(3): 105-120. D0I: 10.18522/2073-6606-2021-19-3-105-120

The factual diarchy in triathlon, as well as the emphasis of its economic model on mass participationall this is atypical for Olympic sports. On top of non-profit International Triathlon Union (ITU), there is also a strong economic competitor - commercial World Triathlon Corporation (WTC) owning the Ironman brand with its own independent World Championships. The reasons for this state are poorly investigated. Analysis of archival documents, memoirs, press publications, as well as interviews with the founders have allowed us to reconstruct the main stages of the socio-economic history of triathlon. The focus is on how the sports governing bodies were created in the 1980s. We also describe the social origins of the first Iron Man race and the birth of triathlon, the rivalry between Hawaii and Nice championships, and the ITU conflicts with WTC in 1990s-2000s. We argue that these conflicts are the continuation of tensions between European representatives and "American alliance" back in 1980s during the creation of the governing body. Their underlying reason is the difference in European and American models of sports. We dispute the opinion about "Russian threat", which caused the collapse of the Union Internationale de Pentathlon Moderne, Biathlon et Triathlon (UIPMBT), plus views on the ITU development as a success story. We show that the causes of UIPMBT collapse and the earlier Triathlon Federation International collapse were due to the personal ambitions of ITU first president Les McDonald, its questionable political technique (so-called "active democracy") and the "Alliance's" economic interests. But in the end, McDonald's backstage victories became Pyrrhic for ITU.

Keywords: triathlon; Ironman; economic history; case study; sport governance; mass participation sport; commercialization of sport; European Sport Model

JEL codes: N40, Z13, Z29

() А.С. Адельфинский, 2021 


\title{
Американская экспансия, русская угроза и активная демократия. Институциональный взгляд на историю триатлона
}

\author{
Андрей Станиславович Адельфинский \\ МГтУ им. Н.Э. Баумана, Москва, Россия, e-mail: adelfi@mail.ru
}

\begin{abstract}
Цитирование: Adelfinsky A.S. (2021). American expansion, Russian threat and active democracy: An institutional perspective on triathlon history. Terra Economicus 19(3): 105-120. DOI: $10.18522 / 2073-6606-2021-19-3-105-120$
\end{abstract}

\begin{abstract}
Фактическая дуархия в триатлоне, а также акцент его экономической модели на массовом участии - всё это нетипично для олимпийских видов спорта. Помимо некоммерческого International Triathlon Union (ITU), существует сильный экономической конкурент - коммерческая World Triathlon Corporation (WTC), владеющая брендом Ironman и своими независимыми чемпионатами мира. Но истоки данного состояния слабо изучены. Анализ архивных документов, публикаций прессы, мемуаров, а также интервью со-основателей позволили нам реконструировать основные этапы социально-экономической истории триатлона. Фокус статьи на создании органов управления спортом в 1980-х. Также описаны социальные истоки рождения триатлона и первой гонки Iron Man, соперничество чемпионатов между Гавайями и Ниццой, а также конфликты ITU и WTC в 1990-2000-х. Утверждается, что эти конфликты - продолжение трений между представителями Европы и «американского Альянса» при создании органа управления в 1980-х. Их подоплёка - в различиях Европейской и Американской моделей организации спорта. Оспариваются мнение о "русской угрозе», ставшей причиной раскола Международного союза современного пятиборья, биатлона и триатлона (UIPMBT), а также взгляды на развитие ITU как на историю успеха. Показано, что причиной раскола UIPMBT и более раннего раскола Triathlon Federation International стали личные амбиции первого президента ITU Лэса МакДональда, его спорные полит-технологии (т.н. «активная демократия»), плюс экономические интересы «Альянса». Однако в итоге кулуарные победы МакДональда стали Пирровыми для ITU.
\end{abstract}

Ключевые слова: триатлон; Ironтап; экономическая история; кейс-стади; управление спортом; массовый спорт; коммерциализация спорта; Европейская модель спорта

\section{Attention to mass participation sports}

"Such world-famous run as the Ironman requested for the next year... There is already an agreement that the first start of Ironman will be in the Russian Federation. It will take place in St. Petersburg" - as was reported to the Russian President Vladimir Putin on 0ctober 21, 2019 at the meeting on the development of physical fitness and sports. By this statement Deputy Prime Minister Olga Golodets emphasized the importance which was given by the Russian Government to mass participation sports ${ }^{1}$. Later, on December 16, 2019, the aforementioned "run" set a record for sales among triathlons. 2000 entry slots were sold at the price of $€ 225$ just within 3 hours from the start of the registration 7 months before the event date. 500 additional slots were agreed and sold as well. This huge demand was created by the Russian non-elite amateurs who bought $88 \%$ of the all slots. For comparison, the 2019 ETU European Triathlon Championships in Kazan gathered only 253 amateurstriathletes from Russia, with the entry fee of $€ 120$, the registration lasted until the technical deadline a week before the event. At the same time this European Championships in Kazan, as well as 
triathlon as a whole, did not receive the attention during the Russian ministerial meetings with the President. The exuberant demand for participation and the State first persons' attention to Ironman 70.3 St. Petersburg also attract attention to the whole triathlon as a unique phenomenon.

Triathlon is unique because its economic model relies on mass participation, it is inclusive as a sport, triathlon races are open to everyone without discrimination by skills. Triathlon rules too are written taking into account massive participation of amateurs of all ages from 16-24, 25-29, 30-34, etc. up to 80-84, 85-89 and older - not just elite athletes. Moreover, the World and European Championships and other top international triathlon events imply their joint participation (Adelfinsky, 2013; Markus, Arimany, 2020). This is unusual for Olympic sports, and at odds with the practice of the International Olympic Committee (IOC), where sport as a whole is a pyramid of qualifying starts with only elite sportsmen and sportswomen at the top only. But at the same time, it makes triathlon a role model for the Council of Europe and the European Sports Charter, where "sport for all" is the key principle ${ }^{2}$. However, at present, the triathlon history is a set of uncoordinated narratives poorly investigated in scientific publications.

So, the purpose of the article is to reconstruct the history of triathlon as a socio-economic phenomenon, with the focus on how sports governing bodies were formed. The paper lays ground for future comparisons of European and American models in mass-participation sports. Understanding these issues is important in view of the objectives of the European Sports Charter to provide "sport for all" and to increase massive grassroots participation.

\section{Diarchy of triathlon as a research problem}

One of triathlon's features, which is not typical for Olympic sports, is the actual diarchy. The IOC recognizes only one organization as the governing body for a particular sport and it is the non-profit international sport federation (IF). It is composed of National Federations (NF), formed by grassroots organizations based on individual membership. The monopoly rights of governing bodies to status events (i.e. the Championships, and Cups at the World, Continents, and Nations levels) make it possible to regulate the sport's "domain", the system of competitions, plus allow to create an economic support for the bodies themselves. The interaction of government bodies and local organizing committees during status events is reminiscent of franchising - the right to the "title" is transferred in exchange for an event rights fee along with a set of conditions and technology.

Unity under the auspices of IOC and IFs, however, is not always observed. There is a known conflict in economically successful sports when commercial leagues compete with IFs for the right to govern in the "domain". Leagues are typical for the USA. The so-called American model of sport considers it as some sort of show business. In contrast, the European model of sport sees it as a socially significant institution and an area of non-profit activity and voluntary work. And the democratically formed system of Athletes-Clubs-NF-IF is a reflection of this model. However, real government practices in specific sports are diverse, changing and poorly investigated (Chappelet, Kübler-Mabbott, 2008).

Triathlon is an interesting but poorly investigated case of actual diarchy. The non-profit International Triathlon Union (ITU) is the federation recognized by the IOC and governing triathlon competitions for Olympic selection system. The World Triathlon Corporation (WTC) is a for-profit company that owns the Ironman, Ironman 70.3 brands and its own competition system, mainly for the "Iron" and "half-Iron" distances.

Both organizations have created their own historical narratives that almost do not notice each other. The ITU's story is about the "Olympic dream" of triathlon, where its main protagonist is the first president, British-born Canadian Les McDonald". Another story is the saga about the "Hawaiian Ironman Championship" 4 as a cult event. Various multilingual "triathlon histories", available on the Internet and in press ${ }^{5}$, mainly built on the basis of these narratives.

\footnotetext{
European Sports Charter 2001. Recommendation No. R (92) 13 Rev. Council of Europe.

Bernhardt G. The History of Triathlon. Active.com. September, 2009. See also: (Springman, 2017).

Ironman 70.3 World Championships Media Guide. WTC, 2013. See also: (Granskog, 1993; Tinley, 2019).

5 Adelfinsky A. The history of triathlon: from Running with Lydyard to the Olympics. 2006.
} 
However, these two main historical narratives mask economic contradictions, significant but inconvenient facts and conflicts of the past. While studying triathlon in Australia, historian Jane Hunt noted: "Both the Ironman and Olympic arms... promoted a collective memory of triathlon that suited their respective claims... [but] they rendered the... memory of early everyday proponents... irrelevant" (Hunt, 2017).

There are also personal stories of witnesses of past events. However, the reconstruction of general history is incomplete and slightly inaccurate. For example, former elite athlete and sociologist Scott Tinley writes "November of 1982. Nice Triathlon, first ever in Europe (we think). ${ }^{6}$ Perhaps this quote accurately reflects the vision of the European history of triathlon in the USA, but contradicts the facts, as we will show below.

\section{Literature review and methods}

At first glance, the academic literature on triathlon is very extensive. For example, scientific platform Dimensions identifies 1,800 works from 1980 to 2020 for the search query triathlon. Most of the papers are focused on the medical-biological, training and psychological aspects of sports, including analysis of statistics. In these articles, triathlon can be represented as a set of distances: Sprint, Olympic, half-Iron, Iron (Rüst et al., 2011; Lepers et al., 2013; Knechtle et al., 2014; Wu et al., 2015; An et al., 2021; Sousa et al., 2021; etc.). At the same time, the socio-economic reality of the triathlon is perceived "as it is", without detailed questions about the history of its formation.

Research in the field of social sciences is represented by only 107 papers. Moreover, the topic of economics is covered by 9 articles, institutional - by 4 articles (Sowell, Mounts, 2005; Baumann et al., 2009; Sallent et al., 2011; Raya, 2012; Wicker et al., 2013; Saghiri, Wilding, 2013; Kim, 2013; Eren, 2017; ParraCamacho et al., 2020; Phillips, Newland, 2014; Wagner, 2016; Pedras et al., 2020; Dori, Kemp, 2020). Only recent articles by Jane Hunt are focused specifically on history (Hunt, 2017; 2019).

A very valuable research by the Americans Sean Phelps and Aubrey Kent, who studied the history of the ITU's creation and development in the theoretical framework of institutional isomorphism (Phelps, Kent, 2010). Phelps' dissertation contains many original quotations and an attempt to present different opinions. But the European side is poorly represented in his study. Appealing to the methodology of social constructionism, Phelps suggested the existence of other interpretations than his own: "I encourage others to find different meanings and explanations from the data based upon their knowledge, experiences, and perspectives" (Phelps, 2006). We accept the challenge.

Following Sean Phelps' work, we also relied on the case study strategy. It is widely used in business and organizational research. This approach goes back to the original institutionalism and historical school of economics (Berghoff, 2001; Hultén, 2005). The case study strategy is characterized by holism, contextuality, adaptability and multi-methodicity, a variety of empirical materials, as well as a narrative form of presentation of results (Polukhina, 2015; Ridder, 2017).

The question of Phelps - is about the reasons for ITU's success story in bringing the Olympic recognition for triathlon in 5 years. Our question - is about general social-economic history of triathlon and about the reasons for governmental diarchy. To answer this question, we require a holistic approach also taking into account the inclusiveness of triathlon and the motives of ordinary amateurs (Lamont, Kennelly, 2019; Adelfinsky, 2021). In contextual terms, our work is based on the premise of the institutional difference between the so-called European and American models of sports. This causes various motives of specific actors. Phelps does not consider this aspect in detail, but points in the discussion to the two contrast "organizational cultures". Previously this difference in models of institutional organizations was explained with a focus on spectacular team sports (Andreff, Staudohar, 2000; Nafziger, 2008; Andreff, 2011). But our focus is on mass participation sports. This article will allow us to continue previous research $(2007 ; 2014 ; 2018)$. The paper can be relevant for sports governance studies (Houlihan, 2012; Waugh et al., 2014; Batuev, Robinson, 2018; Clausen et al., 2018; Dagaev, 2018; Agafonova, 2019; Krieger et al., 2020; Van Bottenburg, 2011; Parrish, 2003; Lang et al., 2019; Gammelsæter, 2020; Cockayne, 2019), institutional and narrative economics (Shiller, 2017; Volchik, Oganesyan, 2014; Volchik, 2017; 2020), as well as contribute to the studies of commercialization of sports (Slack, 2014). 
The empirical basis for the study was the ETU, ITU, TFI, and UIPMB documents, publications in various media, memoirs, and other sources. Several co-founders responded to requests for comment, amplifying with European voices a number of interviews previously conducted by Phelps. We are deeply grateful ${ }^{7}$ for the feedback and documents from the personal archives to the following persons: Erika Koenig-Zenz, Judy \& John Collins, Lynn Van Dove, Tatiana Ardabieva, Con 0'Callaghan, Mart Haruoja, Jef Konings, Rene Meimer, Dick Poole, Václav Vítovec, Joop Van Zanten. Due to the limited volume, the comments are almost not reflected in the article, but they served to triangulate the collected array of information.

The results of the study allowed us to create a holistic narrative of the history of triathlon, perhaps the first in the scientific field. We have combined the narratives of ITU and WTC, describing the most important points and closing the "white spots". Such as: the general context of the European and American models of sports, the economic background of a "USA-versus-Europe battle", the Nice as a competitor to Hawaii, a brief description of the ITU and WTC conflict in the 2000s. Significant result: clarification of the reasons for the collapse of the early triathlon governing bodies in 19881989 and refutation of the myth of the "Russian threat" for triathlon in the "marriage" with modern pentathlon and biathlon. A few of issues are not described due to the limited volume. Such as: the multiplies drivers for the Olympic integration of triathlon in the 1980s, the conflicts between McDonald and ETU in the 1990s and early 2000s, the legal battle over ownership of Hawaiian race, the emergence of the Challenge triathlon series as a competitor for WTC in the 2000s, the Team Unlimited with Xterra, etc. So, below is our own reconstruction of the main stages of the socio-economic history of triathlon.

\section{Early US triathlons and Sports Illustrated article}

Triathlon in the USA has emerged as part of the fitness-boom. “In 1971, at age 35, I joined millions of other Americans in the jogging craze. ... Before I knew it I was competing in road races, which at that time, were relatively small (and inexpensive) affairs", - wrote Jack Johnstone in the opening lines of his triathlon history. It was this math teacher, along with lawyer Don Shanahan, with support of the San Diego Track Club, who came up with an idea and organized the first triathlon in the United States on September 25, 1974. It was a continuous 10-segment multi-race of 6 miles of running, 5 miles of cycling and 500 yards of swimming attracting 47 local recreational athletes. The entry fee was $\$ 1$, which was typical for runs of that time. The precursor of triathlon was run-swim "biathlon" with zero fee, first time organized in 1972 by 50-year-old attorney David Pain, the pioneer of US masters athletics on this birthday. A similar triathlon has been held by 0ptimist Club since 1975 in neighboring Coronado. Although becoming annual events, these races still remained a local phenomenon. But there was a group of four, a Navy family, who eventually had a huge impact on the development of triathlon in the future. It was a 38-year-old marine engineer John Collins, a 35-year-old analyst Judy Collins and their children, Kristin and Michael, took part in the seminal San Diego triathlon ${ }^{8}$. It was Collins family who scaled the triathlon concept into an endurance event.

"Long slow distances were very popular at that time, and we wanted to do one," - explain Judy Collins, who came up with the idea to join two distances, Waikiki Rough Water, and Honolulu Marathon, with a some cycling leg into a single event. John proposed the Around Oahu bike ride. So, on February 18, 1978, Judy and John Collins organized the First Annual Hawaiian Iron Man Triathlon, with the distance of $3.8 \mathrm{~km}$ swim $+180 \mathrm{~km}$ cycle $+42.2 \mathrm{~km}$ run. The race was intended for ordinary recreational athletes, include the Collinses themselves, and everyone who wished to join. Due to the late announcement and bad weather, the first two editions of the race in 1978-1979 gathered only 15 people$^{9}$. However, at the second race there was a casual visitor, a journalist.

In May 1979, Sports Illustrated published a long read called "Iron Man". Its author, Barry McDermott, described the weird contest of 15 people with bad weather and $226 \mathrm{~km}$ distance. The race for-

\footnotetext{
We are also grateful for mediation in the search to: Paul Groves, Eugène Kraus, Andrey Rogatin.

Jonstone J. Triathlon - The Early History of the Sport. 1999.

9 Collins J.M., Collins J.F. A Long Narrative. The woman and the man behind the Ironman. Thiswastriathlon.org, 2012. [Also: personal communication, July 2021.]
} 
mula was so impressive, and it would seem, that the text should be like an epic. But the article turned out as a satirical sketch. The unconventionality and eccentricity of event is conveyed through amusing description. For a handful 30-year-old recreational amateurs to take the start "was a legal way to prove their toughness," but even for the winner, the race was an agony. As a trophy, all the finishers received a small figure made of bolts and nuts, soldered "with a hole in the top, or, you might say, the head". McDermott continues: "The significance of the event is that there is no apparent significance. No prize money is involved, and little fame..."10. The overall tone of the article - describes not a role model, but a funny case, as is, without embellishment. The phenomenon does not have an established name. The local newspaper described the race as the Honolulu Triathlon, and McDermott called it the Hawaiian Iron Man Triathlon.

Sports Illustrated longread received much attention worldwide. In August 1979, Československý Sport published an article entitled "The Agony of the Iron Men."11 The tone of East-European journalist is very much like the American one - it's funny, but eccentric and pointless. However, the readers seemed to have a different view and many decided to test themselves in the race. Next year, at least two triathlons were born in socialist Czecho-Slovakia: near Ceske Budejovice, and Prague. One of them was announced in local press, and 108 athletes conquered the authentic $200 \mathrm{~km}$ cycle $+2 \mathrm{~km}$ swim $+20 \mathrm{~km}$ run distance. The same year, a triathlon half the distance of the Hawaiian one gathered 50 athletes in Indiana, USA. In Smith Falls, Canada, two teenagers staged a small triathlon for schoolchildren. And off it went.

Our conclusion is as follow. Since 1979 the triathlon began to spread around the world. McDermott's story about Hawaiian race give birth to a media virus, which introduced a complex of memes called "triathlon" to a wide audience. Its details are "this is swimming, cycling, running", "the total distance is $3.8+180+42.2$ " and this is "an incredible challenge", the "top efforts, suffering and pain", but "all challengers earned the unofficial titles of Iron Men". The ethos of triathlon was born as the ethos of long distance. Hence, the goal of an enchanted neophyte is to begin with short triathlon distances, but someday to try the very "iron" one, which everyone speaks about.

\section{Beginning of American triathlon expansion}

The response to the "Iron Man" article for the Collinses was "a shoe box full of hundreds of letters from [those] ... who wanted to do the race." John also gave permission to do the broadcasting of the next event to $A B C$ Sports, since "the filming bore him no expense"12. According to the Collinses, the first Iron Man Triathlon was originated from non-profit amateur sports; it "was designed as a low budget, low profile event to be added to the annual calendar of the Waikiki Swim Club". The entry fee of the debut race in 1978 was $\$ 5$ with a small negative balance, in 1978 it was $\$ 8$ with a breakeven budget. But at the end of 1979 the US Navy gave John a new assignment, and the Collinses were looking for someone to take care of the Iron Race. Together with a guarantee of a volunteering support from the Waikiki Swim Club, the "shoe-box" ended up with Hank Grundman, owner of the Nautilus fitness-club. And later, with his wife and co-owner, Valerie Silk. "No money changed hands, no papers were signed", - explain Judy Collins, - "We even did not know Hank's surname, and first time met with Valerie just in 1983"13.

The third edition of the Hawaiian race entitled the Nautilus Triathlon takes place with almost the same fee - $\$ 10$. The race already gathered 108 athletes, and it was broadcast by a leading national TV channel. In 1981, 491 athletes participated in the fourth edition of the race entitled Nautilus International Triathlon. Valerie Silk was meant to organize this sports event gaining in popularity and to commercialize the phenomenon. She sells media rights to TV-giant $A B C$ and signs a contract with title sponsor Budweiser Light beer brand. The collaboration with $A B C$ and $B u d$ Light lasted almost 10 years. On August 6, 1981, the firm Hawaiian Triathlon Corporation, co-owned

\footnotetext{
${ }^{10}$ McDermott B. Ironman. Sports Illustrated. May, 1979.

${ }^{11}$ Valenta Z. Agonie źelezných mužů. Československý sport, 17. srpna 1979.

${ }^{12}$ Ironman Media Guide ...

${ }^{13}$ Collins J.M., Collins J.F. A Long Narrative. ... Also: personal communication via email, July2021. Also: Branch J. The Enduring Fight Over the First Ironman Triathlon. The New York Times, 25.01.2019.
} 
by Silk, registers the "Iron Man World Triathlon Championships" and "Ironman Triathlon" brands" . It is noteworthy that the 1981 edition of the race does not even use the "Iron Man" in the title. But the next edition in February 1982 entitled the Budweiser Light Ironman World Triathlon. And later, in October 1982, the Bud Light Ironman World Championship Triathlon, with $\$ 100$ entry fee.

Another race also broadcast on TV, the U.S. Triathlon Series (USTS), was also sponsored by the same Bud Light in the same years. During the 1980s, it was the most media-visible and trendy triathlon series in the United States. USTS actively worked with sponsors, and generated about 25 media events for ESPN, NBC and other TV-channels on the basis of own competitions. In 1982, it was USTS, who turned triathlon into a professional sport by established the regular monetary prizes. And also introduced a lot of know-how, including their own distance $1.5 \mathrm{~km} \mathrm{swim}+40 \mathrm{~km}$ cycle $+10 \mathrm{~km}$ run. Over 11 years of operation, the USTS has held more than 120 events in 30 locations, mainly in the USA, where more than 100,000 athletes took part and more than $\$ 1$ million in prize money was paid ${ }^{15}$. The USTS was conceived in 1981 by a graduate lawyer, amateur runner, and race organizer Jim Curl, and proposed to Carl Thomas, ex-elite swimmer, and vice-president of Speedo International for sponsorship. Starting as a marketing campaign for Speedo, in 1984 the project became CAT Sport Inc., their own event and production company. In the same year, the series declares its top status by holding inaugural Bud Light USTS National Championships. Thomas also co-founded Triathlon Federation/ USA (Tri-Fed/USA), the predecessor of modern USAT (NF for triathlon in United States). He had a significant impact on its work, particularly with regard to international relations ${ }^{16}$.

In October 1984, worldwide expansion of two American triathlon projects began from Hawaii, where Thomas together with Silk established the Federation International Triathlon (FIT) as the governing body for triathlon in the world and became its president. In 1985 the International Triathlon Team Cup was held. There were two races, the USTS in Chicago and the Ironman Hawaii. In 1986 the USTS found partners and organized the races in Canada and Japan. In 1985-1986 the first Ironman licensees appeared in Canada, Japan, and New Zealand.

Alternative World Championship took place on the French Riviera since 1982. It was the Triathlon International de Nice, Championnat du monde, with its own long distance $4 \mathrm{~km}$ swim $+120 \mathrm{~km}$ cycle + $30 \mathrm{~km}$ run. It was invented and organized by famous sports agent Mark McCormack and his company $I M G$. Media rights were intended for $C B S$ broadcaster, the direct competitor of $A B C$. Prior to the ITU creation in 1989, the Nice Triathlon successfully competed in importance with the Hawaiian one, attracting national champions. In 1985, two self-proclaimed championships were held on close dates. If in Nice $\$ 75,000$ were raffled, in Hawaii there were no monetary prizes yet; and thus, the majority of elite athletes preferred Nice ${ }^{17}$. It also turned out that the French triathlon is older than the American one. There were publications, photos and even participants themselves, proving the existence of short 3-segment multi-races in the 1920s-1930s.

We must emphasize that Phelps and Kent do not mention the "competition of championships" between Hawaii and Nice, as well as all other official narratives. It should also be noted that both events as "world championships" presented themselves only since 1982 and not earlier.

\section{FTI, the first attempt to establish the unified governing body}

In parallel the struggle for international political dominance and a single governing body in the world of triathlon began. It was a "USA-versus-Europe battle, with Thomas and his FIT on one side and the Europeans, consolidating under the ETU banner" - wrote American magazine Triathlete ${ }^{18}$.

European Triathlon Union (ETU) was founded half year earlier than FIT, on April 7th 1984, in the German city of Cologne. Then, on August 8th, in the Dutch city of Almere, the first executive committee was elected, including President Con 0'Callaghan (Ireland) and Secretary General Joop Van

\footnotetext{
${ }^{14}$ JUSTIA trademarks (http://rademarks.justia.com/owners/world-triathlon-corporation-255524/)

${ }^{15}$ Baird M. Up close with tri legends Jim Curl and Carl Thomas. 220triathlon.com, July 15, 2013. Plant M. Jim Curl Does Geraldo. Trihistory.com, October 19, 2015.

${ }^{16}$ Curl J. The US Triathlon Series (USTS) History: 1982-1993. USAT History Project, 2011.

${ }^{17}$ Camous I., Huot-Jeanmaire F., Gasquet F. (2013). 30 ans du triathlon de Nice 1983-1992. Ligue CA \& FFTri, p. 15.

${ }^{18}$ Johnson H. Shifting alliances. Triathlete, June 1988.
} 
Zanten (Netherlands). In 1985-1987, the ETU system of top status competitions contained three annual European Championships at 1/4, 1/2 and full "iron" distance ${ }^{19}$. The "short" preceding the "half" and "long".

ETU members refrained from recognizing the FIT due to different approaches to the organization, as well as because of Thomas's conflict of interests. Being the co-owner of commercial CAT Sports, Thomas formally acted as FIT President and Tri-Fed/USA spokesman. At the same time, the ETU emerged and developed as a non-profit federation based on the European model. Thus, "members of the ETU also discussed "the need for a unified international body" but were leery of Thomas' motives and viewed the FIT as a means for him to advance his "own private ambitions in the sport"" - wrote Triathlete $^{20}$. But there was an active dialogue. In October 1985, at the GAISF meeting, both ETU and FIT confirmed among their goals "possible inclusion in the Olympics", which implied a single body. As early as February 1987, in Dallas ETU and FIT agreed on the new election procedure, new charter, and even a new name.

Federation Triathlon International (FTI) was founded in November 1987 in Amsterdam. The future calendar of the unified body included two annual World Championships on the "short" $(1.5+40$ + 10) and "long" (3.8 + 180 + 42) distances. In 1988, the "short" one was planned in Kelowna, Canada; and the "long" one in Hawaii. Then in 1989, the championships were supposed to be in France and Japan. In 1990 - in Argentina and Canada. The executive board was elected, including Treasurer David Curnov (USA), Secretary General 0'Callaghan and President Van Zanten (both resigned from ETU). Moreover, Valerie Silk was also elected to the FTI executive board, and agreed not to use the "World Championship" title for the Hawaiian Ironman in the future.

But in January 30,1988, US executives ignore the FTI's meeting in Canada. Instead, they send the Tri-Fed/USA memorandum with new terms. Likewise, in February Silk changes her previous decision: "If the U.S. doesn't participate in the world body, there is no world body. And if there is no world body, then the Ironman can't recognize its authority." Triathlete commented this situation: "The Europeans were... counting... on the prestige of officially associating with the most important race in the world... [However] the strings attached to being an "official" [for Hawaiian] world championship were not insignificant" 21 .

But our conclusion is different. This struggle was just about the status "official". In the 1980s, the recognition of a number of "world championships" (i.e. Nice and Hawaii on "long", and Perth and Kelowna under the FIT banner on "short" distances) depended on personal bias of specific media, sponsors and countries. For example, in 1988, the Californian Los Angeles Times called the French start the Nice World Championship Triathlon, while the Hawaiian one was just the Ironman Triathlon ${ }^{22}$. The official IF could confirm the status or, on the contrary, "to bring down stocks" for selfproclaimed projects. It can be noted, that year Silk was trying to sell the Hawaiian Triathlon for $\$ 2$ $\mathrm{mln}$, but the deal falls ${ }^{23}$. We also believe that the background of the struggle was a conflict of different ideas - i.e. varied institutional organizations of sports in European and American traditions. The ETU' obvious position: the championship cannot be private. At the same time, the American "alliance" defended its business interests.

When the FTI was established in 1987, a compromise was found. On the one hand, the European side has a majority. It was opposed by the USA, Canada, Australia, New Zealand and Japan. This corresponds exactly to the geography of Thomas and Silk licensees. Weighting voting was proposed, which significantly increased the "voice" of large federations. The Tri-Fed/USA received 8, small NFs 2 each, in total there were 67 votes from 25 countries. However, the European candidate won 51 vs 16 against the "alliance" candidate Phil Briars. On the other hand, North America had the right to organize half of the world championships for the next 3 years and 4 seats in the executive board. But it seems that this was not enough. Discussing the Tri-Fed/USA memorandum, Canadian Les Mc-

\footnotetext{
${ }^{19}$ On top of three individual championships, there was also a team one.

${ }^{20}$ Johnson, 1988.

${ }^{21}$ Ibid.

${ }^{22}$ Klein G. Big Mac Attacks Triathlon Circuit: MacNaughton Expects to Contend Seriously During Upcoming Season. Los Angeles Times, 24.01.1988.

${ }^{23}$ U.S. Court of Appeals, 9th Cir. No. 89-15557. 25 April, 1990 (http://law.justia.com/cases/federal/appellate-courts/F2/902/39/165251/).
} 
Donald and New Zealander Phil Briars proposed new concessions to the Americans. As explained by 0'Callaghan, this included: strengthening the Tri-Fed/USA "voice" up to 25 votes at the FTI conference, electing Thomas as Vice-President, canceling the 1988 World Championships, and transferring 1989 World Championships from Japan and Argentina to the United States ${ }^{24}$. Van Zanten's remark in the Triathlete was: "we do want Americans in, but at what cost?"25

\section{UIPMBT $^{26}$, the second attempt of the unified governing body}

Part of Olympic movement's economic reforms in the 1980s was integration of new growing sports. The IOC President, Juan Antonio Samaranch-Sr., was informed about the triathlon failures with a single body. In April 1988, Samaranch-Sr. proposed to Sven Thofelt, President of the Union Internationale de Pentathlon Moderne et Biathlon (UIPMB), to take triathlon "under his wing". Moreover, with a prospect of demonstrating the new sport already at the 1992 Olympic Games in Barcelona. Thofelt kindly supported the idea. He invited the representatives of the national triathlon federations to the UIPMB Executive Committee on August 20-21, 1988 in Stockholm. Thofelt gave assurances of the "freedom and autonomy within". And representatives of 23 countries unanimously decided to provisionally join the UIPMB. At the same time, the "Working Committee of triathlon" was formed of 7 people, including the two co-chairmen: Les McDonald and Sture Jonasson (Sweden). The task of the Committee was to prepare the future 1989 UIPMBT World Triathlon Championships and documents for the final integration. According to the plans, the World Championships were supposed to include two distances: "short" and "long"27. Then on 18-19 November, 1988 the UIPMB Assembly in Montecatini approved the adoption of the new sport triathlon almost unanimously. Igor Novikov (USSR) chaired the Assembly and was elected the new UIPMBT President, since Thofelt resigned due to illness. However, the second body did not succeed, just like the first one.

The UIPMBT project ceased to exist on April 1,1989 at the Papal Palace of Avignon, at the ITU founding congress. Most of Phelps's sources associate the UIPMBT collapse with the position of the "Russian guy" Igor Novikov. According to American Mark Sisson, the new leaders of UIPMB did not even understand the triathlon rules: "these guys just didn't get it. That they were proposing that the swim be on day one, the biking on day two and the run be on day three". A similar view was presented by Briton Peter Coulson: "it had been suggested by the IOC... to become a 'section' within UIPMB then that would be the quickest route to Olympic inclusion. [But] the leadership of UIPMB was all from Eastern Europe. [And] McDonald had other ideas ... a separate and self-governing body would be the best solution. Because... [in case it had become a 'section'] triathlon would be simply rubbed out by UIPMB"28.

According to Triathlete magazine, Novikov did not show diplomacy at the right moment, which scared away even the supporters: "[West German Dr. Martin] Engelhart led the discussion in favor of the UIPMB... In a moment ... Carl Thomas agreed to the vote ... [if] UIPMB accept the by-laws that had been approved ... [before]. Engelhart put the question to Novikov. Would he and the UIPMB accept triathlon with its by-laws? Novikov, a bear of a man ... more than 260 pounds, lumber up to the microphone and, in essence said, "Nyet." Novikov had made the fatal error. Faced with the opportunity to say, "Well, I really can't make that kind of decision here, but I'll take it back to the executive for consideration," the Russian alienated the entire room of triathlon supporters with his patented answer, "No rule changes, no elections, no nothing!"29

Alternative opinion (relative to other sources from Phelps) was voiced by the Austrian Erika Koenig-Zenz: “USA formed one block together with Australia/NZL/Asia against Europe. The IOC on the other hand saw that triathlon could replace the unloved Modern Pentathlon on the Olympic Program and wanted by all means that triathlon become a part of the Modern Pentathlon federation. At the

\footnotetext{
${ }^{24}$ O’Callaghan C. Worlds Apart. Triathlon Ireland, No.8, Summer, 1998.

25 Johnson, 1988.

26 This title was used in the Soviet press and official reports in 1989. See GARF, R7576-34-3750.

27 ITU founding congress Minutes. March $31^{\text {st }}-$ April $1^{\text {st }}, 1989$, Avignon, France.

28 Sisson M. - cited from (Phelps, 2006: 76-77); Coulson P. - (Ibid, 74).

29 Olivares Jr. Power politics. Triathlete, July 1989 - cited from (Phelps, 2006: 73-74).
} 
"founding congress" of the ITU 1989, the decision to merge with Modern Pentathlon should be taken but McDonald gave all a "demonstration in active democracy" (direct quote) and had the congress 1 hour earlier than scheduled. All those who were against an own federation came too late. Congress voted for an own federation" ${ }^{130}$.

\section{ITU, the salvation from Russians or the "active democracy"?}

What was the reason that the UIPMBT was wrecked? Surprisingly, that Koenig's version of the role of "active democracy" at the April congress in Avignon was confirmed by McDonald himself. 12 years later, he confessed to The Guardian: "We had a congress election at $10 \mathrm{am}$, so I got everyone down there by $9 \mathrm{am}$, had the election, and when the Russians came, it was all over, goodbye. We gave them an example of active democracy" ${ }^{\prime \prime}$.

The documents brought a lot of clarity. Firstly, in 1989 the UIPMBT office was in West Berlin, the executive committee had 6 people from Western Europe and only 3 from Eastern Europe, including only one Russian - Novikov. Secondly, it was the countries of Western Europe (Austria, Belgium, Italy, Germany, Liechtenstein, Luxembourg, Netherlands, and Switzerland) that protested the break up with the UIPMBT already at the April congress. Thirdly, the dispute was not about the triathlon rules, but about the UIPMBT charter. According to the UIPMBT view, triathlon was given equal rights with biathlon and pentathlon. At the same time, the triathlon NFs became members of the UIPMBT, with the election of a new Vice-President of a new sport. But the desire of the "Working Committee of triathlon" was a Union within a Union with its own president. And the most important thing is that the UIPMBT did not recognize April election results due to manipulations, and expected new ones ${ }^{32}$ Camillo Cametti, President of the Federazione Italiana Triathlon outlined other details, in addition to the hourly time-shift: "The election were totally unacceptable, a complete farce: no notification of candidature, no secret ball-out, all the members of the Working Committee have been elected in a way that everybody should be shamed"33.

Ironically, since 1988 the UIPMBT funded the "Working Committee" by $\$ 25,000$ and recommended to the National Olympic Committees to recognize the new triathlon NFs. It seems that these new flags with disputed statuses or its proxies have become an additional factor for the victory of "active democracy". This was reflected by Cametti: "The winning side wans 17 to 14: a majority of 3 votes, of which at least 5 were illegal". About later ITU expansion, Mark Sisson confessed: "The nature of the organization was such that in the early days we had to do that required more liberal interpretation of the rules. Certainly, the number of federations that we created ... Anyone [can] said: I think this federation that you got running out of this guy's garage, uh, in Ivory Coast is probably not really a federation" 34 .

This "active democracy" seems to have served as a tool for McDonald on several occasions. The ITU elections in April 2000 received scandalous publicity. ETU Secretary General Erica Koenig-Zenz was nominated as an alternative to McDonald by a number of countries. However, he retained his chair, by rejecting the mandates of 13 disloyal delegates. And also by secretly distributing "information packets" about the alleged expulsion of triathlon from Olympics, if he is not elected ${ }^{35}$. The case continued in the British Columbia Court (Canada), where the judge fully confirmed the fraud, but avoided reviewing the elections (Downes, 2020).

Probably the first case of "active democracy" was the TFI collapse in 1988. Explaining the situation, 0'Callaghan and Belgian Jef Konings reported "the curious behavior of [TFI executive board member] McDonald." In January 1988, he offered to accept the Tri-Fed/USA new terms. But having failed to get support, McDonald "attempted to browbeat into agreement by resignation" of Canada and New Zealand from TFI membership. The factual resignation took place only in March, leading to

\footnotetext{
${ }^{30}$ Koenig-Zenz E. - cited from (Phelps, 2006: 74).

${ }^{31}$ Downes S., Nawrat C. Run, swim, duck and dive. The Guardian, 22 July 2001.

${ }^{32}$ Triathlon as a provisional UIPMB-Member: Information to all NF triathlon, signed by Dieter Krickow (UIPMB), 23.07.1989.

${ }^{33}$ Letter to ETU, signed by Cametti (Federazione Italiana Triathlon), 13.04.1989.

${ }^{34}$ Sisson M. - cited from (Phelps, 2006: 139).

${ }^{35}$ Downes, Nawrat, 2001. Kennedy A. The ill-will Games. Inside Sport, August 2000.
} 
the cancellation of the short TFI World Championship in Kelowna, Canada and 4 months losses. And later the Kelowna championship "ran" under the TIF banner of Thomas ${ }^{36}$. This led to financial and reputational costs for the TFI championship in a new European location, and cancel it too.

Of note is the memoir of Lynn Van Dove, director of Ironman Canada in the 1980s. Talking about a night stroll through Amsterdam after the 1988 TFI elections, she described McDonald's eccentric behavior: "Dancing and punching his way down a cobblestone street, he screamed, "I hate being at someplace where nobody knows me!"37 When asked directly about the reasons for the breakup of TFI, Van Dove replied: “The short answer is that Les McDonald's and the New Zealand delegate didn't like that the leadership was in the hands of the Europeans. So, somehow they changed it" ${ }^{\prime \prime 3}$.

The picture is complemented by Thomas' business-partner, Jim Curl. He notes that "McDonald was a great ally." It is noteworthy that Tri-Fed/USA in 1987-1989 was in a state of "civil war." Before each of the two international splits, Tri-Fed/USA forced to resign its executive directors, Verne Scott and Jim Freim. Moreover, the last one was dismissed because he "failed to fully satisfy the needs of the sport's two largest race organizations - the Bud Light Ironman and Bud Light US Triathlon Series" ${ }^{\prime 39}$. But for Tri-Fed/USA McDonald already "played the role of Henry Kissinger", reconciling insiders before the trip of the "delegation ... headed by Carl Thomas" 40 to Avignon. By occupation, McDonald was a trade union leader, a successful organizer of a number of strikes. We believe that his alliance with Thomas became the union of a politician and a businessman. Eventually, one became president and the other treasurer for the independent ITU in 1989.

The "Russian threat", it seems, was artificially invented for intimidation. Novikov's personality served as a good texture for this purpose. He was elected UIPMBT President for his merits as an elite athlete, ascribed also probable qualities of a diplomat and a manager. This turned out to be a mistake. In his memoirs, Novikov admitted his "difficult character", plus his ability "to fight not on the lobby, but in the sports arena"41. He did not know English or any other languages besides Armenian and Russian, required a translator. Also, the Western "Committee" members were not only functionaries, but recreational triathletes. As opposed to them, Novikov and Lev Matyushenko (Soviet member of the "Committee") were the only officials, having long lost their athletic fit. For the triathlon they were not "ours". We believe that the demonization of the "120 kg East-European enemy" allowed McDonald to mobilize his block.

Why did Western Europeans, who sympathized with UIPMBT, nevertheless enter the ITU in 1989, de-facto agreeing with "active democracy"? Probably, the North Americans would have left again in her absence. At the same time, McDonald was able to assure most countries of the early success of the Olympic integration outside of the UIPMBT. That is, demonstration of triathlon is already in Barcelona-1992 and full participation in the next Olympics. This belief held up until the IOC session in September 1990. But the real consequence of the split was the emerging diarchy.

\section{Post-Avignon: WTC expansion and ITU objections}

Hawaiian triathlon in late 1989 was sold to a new owner for $\sim$ 2-\$3 million. Instead of Hawaiian Triathlon Corporation the World Triathlon Corporation (WTC) was established. Throughout the next decade the firm continued the old business model. It organized only one Hawaiian triathlon, called "World Championship", and was licensing the rights to include events in its selection system and to use Ironman brand. At first, its system remained moderate, with 21 "qualifying" races in 1989, and 22 in 1999. Inside USA, these were races under their own names, mostly "half"-triathlons. The Ironman brand had been licensed in 1989 for just 5 races outside USA. These were triathlons in New Zealand, Japan, Canada, Australia, and Germany. By 1999, just 3 more were added: in Brazil, Spain and Switzerland.

\footnotetext{
${ }^{36}$ Letter to Frank Schatz (ETU), copy to Engelhardt (DTU), signed by O'Callaghan (TFI), 26.04.1988.

${ }^{37}$ Van Dove L. Triathlon goes International, 87-90. ShyGiants.com.

${ }^{38}$ Van Dove L. Personal communication via email, May 2020.

${ }^{39}$ Hold the Press. Big change at Tri-Fed/USA. Triathlete, Sept. 1989.

${ }^{40}$ Plant M. The Summit. Triathlon's civil war ends. Triathlete, April 1989.

${ }^{41}$ Novikov I.A. Thirteen starts. SPb., 2004. [in Russ.]
} 
In the 2000s, the WTC business model changed. Previously, the corporation licensed others races. Now it began to organize its own and buy the event businesses of its licensees. In 2005, the Ironman 70.3 brand was born, to represent what was formerly modestly called "half"-triathlons. In 2006, the second championship for the new brand was established and the second "qualifying" race system was built. The Great Recession hastened the expansion process. In 2008, the WTC was acquired by the Providence Equity Partner, a private investment firm, for $\sim \$ 50-\$ 85$ million. In the era of the US Federal Reserve's $0.5 \%$ rate, WTC began borrowing and buying new assets - local mass participation races - on an international scale. In 2015, the WTC was sold to the Wanda Group conglomerate for $\$ 650$ million (but unofficially, taking into account debts: for $\$ 888$ million). Its annual income was estimated at $\$ 183$ million, with an average growth of $21 \%$ over 4 years. The firm managed 219 events, 42 of them in Europe ${ }^{42}$. And this was not only Ironman, Ironman 70.3 races and triathlons but also mass participation runs, marathons, duathlons and bicycle races. For comparison, average annual income of the ITU in $2010-2014$ was $\$ 5.8$ million, of which $47 \%$ is a subsidy from the IOC.

"Cold War" between the ITU and the WTC lasted from mid-1990s to early 2010s, spanning nearly the entire period of McDonald's rule. Defending its monopoly on the World Championships, the ITU tried to negotiate with the WTC. In particular, it offered the status of the long ITU championship for 10 years. But the firm rejected the offer, saying, "We were here first". The ITU then began to put pressure on the USAT, so that they withdraw permissions for Ironman races. In response, the WTC filed a lawsuit against ITU, USAT and Les McDonald in the Tampa City Court (USA). And in 1998 McDonald capitulated by signing an amicable settlement. Another conflict arose in 2005, when the WTC changed its business model, introduced its own rules and a second championship. At the initiative of USAT, the ITU Congress unanimously adopted the loud statement: the WTC is "expelled" from triathlon, NFs are not allowed to sanction its races ${ }^{43}$. But in 2006, the matter again came to nothing.

\section{Discussion on the impact of "active democracy"}

It should be noted that the ITU's declaration on the WTC "explulsion" reproduces the same position as the Council of Europe's declarations to defend of the European model of sport (Nafziger, 2008). Commercial mass participation races are de-facto focused on the premium audience. Thus, buying the WTC franchise means a rise in the entry fees for the same event. An example is the Puhajärve Triathlon (Estonia). The independent race for $€ 40-€ 60$ in 2009-2014, and the Ironman 70.3 franchisee for $€ 215$ in 2015 , both are de-facto identical. At the same time, commercial races are taking resources away from alternatives. Both from "below", local non-profit races and from "above", IFs' titled event. (Note that the report to President Putin on the Ironman "run" obviously highlighted as "non-profit organizations are supported with the grants"). But if non-profit IFs channel their surpluses into the sport development, then the purpose of the business is profit. ITU's annual losses due to competition with WTC can be estimated at \$2.0-2.7 million at the very minimum. The loss of sports due to Americanization of the European model is not only the amount of profit, but a noticeable decrease in economic accessibility; the gentrification of mass sports, the transformation not into sport for all, but into something like Le Derby d'Epsom or The Kentucky Derby (Adelfinsky, 2018b).

What are the reasons for the WTC successful expansion vs relative poor economic performance of ITU's? The WTC "production's secret", we believe, is the ownership of a significant element of "Iron" within the complex of cultural information known as "triathlon". Plus there is its own world championship, which maintains the importance of this "Iron" element, the association with the top-level and also the continuing fitness boom, that is, the influx of new customers.

The Olympic rings are a strong brand in world of sports, but participation in the IOC Games is not available to ordinary athletes due to the level of skills. The situation is different with mass participation sports, including Ironman - anyone can participate, you just need to pay a fee. The career of an ordinary athlete does not develop "from the 'Fit for Labor and Defense' badge to the Olympic medal",

\footnotetext{
${ }^{42}$ Empfield, D. Ironman's Recapitalization. Slowtwitch.com. 07.08.2014. Empfield D. Ironman sold to Dalian Wanda. Slowtwitch.com. 26.08.2015. Wanda Group acquires Ironman for equity value of $\$ 650$ million from Providence Equity Partners. Lava Magazine. 26.08.2015.

${ }^{43}$ ITU 2005 Congress votes to no longer sanction Ironman. ITU. 14.09.2005.
} 
but from 5-km runs to marathons, triathlons and multi-stage races (Adelfinsky, 2021). A neophyte usually learns about a triathlon as follows: "Triathlon? These are swimming, cycling and running. Distances? There is a sprint, "olympic", "half", and the most prestigious is "Iron Man"". This word is used as a usual name for the distance, but at the same time it remains a brand. Although the experience of participating in "iron" triathlons does not depend on the brand, the irrational component of "quality" is associated with the name. The choice of Ironman relatively independent races usually explained in terms "original", "genuine", "official".

In turn, the path of the official body under McDonald' rule led to diarchy, as we believe. The Olympic debut of triathlon was delayed by the UIPMBT collapse until the 2000 Sydney Games, and provisional status was only obtained in 1994. ITU needed to find the required number of membercountries, to obtain the old IFs consent, and to seek the IOC members favor. To do this, McDonald even had to crawl into closed meetings through the toilet window. During the first 5 years, the ITU forgot about the "long" championships and held only a "short" one $(1.5+40+10)$, while getting rid of Nice championships. We believe this only strengthened the WTC. The long ITU championships finally emerged in 1994, but was not associated with any Olympic qualification system for the elite.

The focus on "short" triathlons reflected American influence, we guess. "Carl Thomas was an integral part of the ITU," explained Sisson. ${ }^{44}$ But in September 1993, the USTS was closed, possibly due to the shift in sponsor and TV audience tastes, possibly due to the extra-costs of Olympic dream; and Thomas was out of the game. Without an ally, the previously efficient striker McDonald turned out to be a weak "business executive", although he held the chair of ITU President for 20 years. The underlying reason for the ITU elections conflict in 2000 was poor economic performance. The reasons for which The Guardian and other media saw in the personality of ITU President.

\section{Conclusion}

Why is there the diarchy in triathlon? Or, in economic terms, why does the industrial organization look exactly as we see it? Answering this question set by Ronald Coase, it necessary to expand the allegory proposed by Alfred Chandler Jr. There is no "invisible hand", but there is a rivalry of "visible hands", driven by various motives, from ideal-inspired to rent-seeking. If the early ETU's strategy were continued today, the entire triathlon at the global level could be governed by non-profit organizations. But an "active democracy" intervened. So is the ITU story a success story? We do not think so. It seems that McDonald artificially invented the Russian "threat" for the sake of private interests and to break up UIPMBT. But then a train of internal conflicts prevented the ITU from becoming the sole "sovereign" of the triathlon. The main problem is the "Americanization" (i.e. commercialization) of European model in this inclusive mass participation sport. Economically significant part of the world triathlon has turned from a network of independent organizers in the NFs legal field into an international corporation. Can this be seen as a challenge for the whole IOC system and for the European Sports Charter? It is a topic for the future research ${ }^{45}$.

\section{Литература / References}

Adelfinsky A.S. (2013). A pyramid or an iceberg? Various sports models and their economic implications. Logos 95(5): 139-158 (in Russian).

Adelfinsky A.S. (2018). Despite the Records. An Inquiry into Mass Participation Sports. Moscow: Delo Publ. (in Russian).

Adelfinsky A.S. (2018). New frontiers for fitness. Early history of fitness boom and mass sports development in USA. The Moscow University Herald, series 21 (State and Society) (4): 61-78 (in Russian).

Adelfinsky A.S. (2021). Ordinary, adequate, and crazy: Reconsidering the "pyramid" metaphor for mass-participation sports. The Russian Sociological Review 20(2): 224-249. DOI: 10.17323/1728192x-2021-2-224-249

\footnotetext{
${ }^{44}$ Sisson M. - cited from (Phelps, 2006: 177).

${ }^{45}$ While we were doing this article, the WTC changed its owner, also the ITU renamed itself the World Triathlon.
} 
Adelfinsky A.S. (2007). Triathlon, as it is understood by the political economy lecturer. Moscow (in Russian).

Agafonova R. (2019). International Skating Union versus European Commission: Is the European sports model under threat? The International Sports Law Journal 19(1-2): 87-101. D0I: 10.1007/ s40318-019-00155-6

An B., Sato M., Harada M. (2021). Grit, Leisure Involvement, and Life Satisfaction: A Case of Amateur Triathletes in Japan. Leisure Sciences. DOI: 10.1080/01490400.2021.1927269

Andreff W. (2011). Some comparative economics of the organization of sports: competition and regulation in North American vs. European professional team sports leagues. The European Journal of Comparative Economics 1(8): 3-27.

Andreff W., Staudohar P.D. (2000). The Evolving European Model of Professional Sports Finance. Journal of Sports Economics 1(3): 257-276. DOI: 10.1177/152700250000100304

Batuev M., Robinson L. (2019). Organizational evolution and the Olympic Games: the case of sport climbing. Sport in Society 22(10): 1674-1690. DOI: 10.1080/17430437.2018.1440998

Baumann R.W., Matheson V.A., Muroi C. (2009). Bowling in Hawaii. Journal of Sports Economics 11(4): 397-421. DOI: 10.1080/16184742.2011.599208

Berghoff H. (2001). Business History. International Encyclopedia of the Social \& Behavioral Sciences, 1421-1426. DOI: 10.1016/B0-08-043076-7/02649-8

Chappelet J.-L., Kübler-Mabbott B. (2008). The International Olympic Committee and the Olympic System: The governance of world sport. London: Routledge. D0I: 10.4324/9780203893173

Clausen J., Bayle E., Giauque D., Ruoranen K., Lang G., Schlesinger T., Klenk C., Nagel S. (2018). International sport federations' commercialisation: A qualitative comparative analysis. European Sport Management Quarterly 18(3): 1-20. DOI: 10.1080/16184742.2017.1406970

Coase R.H. (1972). Industrial organization: A proposal for research, pp. 59-73. In: Fuchs V.R. (Ed.) Economic Research: Retrospect and Prospect, Volume 3, Policy Issues and Research Opportunities in Industrial Organization. NBER.

Cockayne D. (2019) Whose side are we on? Balancing economic interests with social concerns through a service-thinking approach. European Sport Management Quarterly 21(1): 1-19. DOI: 10.1080/16184742.2019.1674354

Dagaev D.A. (2018). Decision-making in international sports organizations - A survey. Journal of the New Economic Association 4(40): 167-174. D0I: 10.31737/2221-2264-2018-40-4-8

DiMaggio P., Powell W. (1991) The Iron Cahe Revisited - Institutional Isomorphism and Collective Rationality. The new institutionalism in organizational analysis. 63-82.

Dori S.B., Kemp A. (2020). Undoing age, redefining gender, and negotiating time: Embodied experiences of midlife women in endurance sports. Time \& Society 29(4): 1104-1127. DOI: $10.1177 / 0961463 \times 20948987$

Downes S. (2002). Penny wise, pound foolish... Sport and The Law Journal 10(1): 6-9.

Eren C.P. (2017). Estranged Labor, Habitus, and Verstehen in the Rise of Extreme Endurance Sports. Journal of Sport and Social Issues 41(5): 384-401. D0I: 10.1177/0193723517719663

Fligstein N. (2008). Chandler and the sociology of organizations. Business History Review 82(2): 241-250. DOI: 10.1017/S0007680500062747

Gammelsæter H. (2020) Sport is not industry: bringing sport back to sport management. European Sport Management Quarterly 21(2): 1-23. D0I: 10.1080/16184742.2020.1741013

Granskog J.E. (1993). In search of the ultimate: Ritual aspects of the Hawaiian Ironman Triathlon. Journal of Ritual Studies 7(1): 3-25.

Houlihan B. (2012). Sport policy convergence: a framework for analysis. European Sport Management Quarterly 12(2): 111-135. DOI: 10.1080/16184742.2012.669390 
Hultén S. (2005). Historical school and institutionalism. Journal of Economic Studies 32(2): 169178. DOI: $10.1108 / 01443580510600940$

Hunt J.E. (2017). Toward an alternative to the virtual museum concept: Collective memory and the search for an inclusive approach to digital triathlon history making. Journal of Sport History 44(2): 287-305. DOI: 10.5406/jsporthistory.44.2.0287

Hunt J.E. (2019). In search of a meaningful story: Oral history and triathlon memory in Australia. The InternationalJournaloftheHistoryofSport36(13-14):1-16.DOI:10.1080/09523367.2019.1691534

Kim D.-Y. (2013). Effects of endurance and strength training of cyclists and triathlon athletes on efficiency, economy and V02 kinetics. Journal of Digital Convergence 11(11): 491-498. D0I: 10.14400/jdpm.2013.11.11.491

Knechtle R., Rüst C.A., Rosemann T., Knechtle B. (2014). The best triathletes are older in longer race distances - A comparison between Olympic, Half-Ironman and Ironman distance triathlon. Springerplus 18(3): 538. DOI: 10.1186/2193-1801-3-538

Krieger J., Pieper L.P., Ritchie I. (2020). International federations and national governing bodies: The historical development of institutional policies in response to challenging issues in sport. Sport History Review 51(1): 1-6. D0I:10.1123/shr.2020-0005

Lamont M., Kennelly M. (2019). Sporting hyperchallenges: Health, social, and fiscal implications. Sport Management Review 22(1): 68-79. D0I: 10.1016/j.smr.2018.02.003

Lang G., Ströbel T., Nagel S. (2019) Professionalization forms in mixed sport industries: is it time to rethink the stereotypes of non-profit and for-profit sport organizations? Managing Sport and Leisure 24(4): 1-18. D0I: 10.1080/23750472.2019.1611470

Lepers R., Knechtle B., Stapley P.J. (2013). Trends in triathlon performance: Effects of sex and age. Sports Medicine 43(9): 851-863. D0I: 10.1007/s40279-013-0067-4

Markus G., Arimany A. (2020). ITU Triathlon History. In: Migliorini S. (Ed.) Triathlon Medicine. Springer, Cham. D0I: 10.1007/978-3-030-22357-1_1

Nafziger J.A.R. (2008). A comparison of the European and North American models of sports organisation. The International Sports Law Journal 3-4: 100-107.

Parrish R. (2003). The politics of sports regulation in the European Union. Journal of European Public Policy 10(2): 246-262. D0I: 10.1080/1350176032000059026

Parra-Camacho D., González-García R.J., Alonso-Dos-Santos M. (2020). Social impact of a participative small-scale sporting event. Sport Business and Management: An International Journal 11(2): 109-124. DOI: 10.1108/sbm-12-2019-0119

Pedras L., Taylor T., Frawley S. (2020). Responses to multi-level institutional complexity in a national sport federation. Sport Management Review 23(3): 482-497. D0I: 10.1016/j.smr.2019.05.001

Phelps S. (2006). The creation and development of an international sport federation: A case study of the International Triathlon Union from 1989-2000; PhD Thesis. Florida State University.

Phelps S., Kent A. (2010). Isomorphism and choice in the creation and development of an international sports federation: a review of the International Triathlon Union. International Journal of Sport Management and Marketing 8(3-4): 277-294. D0I: 10.1504/IJSMM.2010.037509

Phillips P., Newland B. (2014). Emergent models of sport development and delivery: The case of triathlon in Australia and the US. Sport Management Review 17(2): 107-120. DOI: 10.1016/j.smr.2013.07.001

Polukhina E.V. (2013). Case-study as a research strategy. Case-study - educational and research experience in an interdisciplinary context. Sankt Petersburg: HSE (in Russian).

Raya J.M. (2012). Length of Stay for Triathlon Participants in the Challenge Maresme-Barcelona. Journal of Sport and Social Issues 36(1): 89-105. DOI: 10.1177/0193723511433868

Ridder H.G. (2017). The theory contribution of case study research designs. Business Research 10: 281-305. DOI: $10.1007 / s 40685-017-0045-z$ 
Rüst C.A., Knechtle B., Knechtle P., Rosemann T., Lepers R. (2011). Personal best times in an Olympic distance triathlon and in a marathon predict Ironman race time in recreational male triathletes. Open access journal of sports medicine 2: 121-129. DOI: 10.2147/0AJSM.S23229

Saghiri S., Wilding R. (2013). Go for gold - winning the supply chain triathlon: creating social, economic and environmental value. International Journal of Logistics Research and Applications 16(6): 445-446. DOI: 10.1080/13675567.2013.860434

Sallent 0., Palau R., Guia J. (2011). Exploring the Legacy of Sport Events on Sport Tourism Networks. European Sport Management Quarterly 11(4): 397-421. DOI: 10.1080/16184742.2011.599208

Shiller R.J. (2017). Narrative Economics. American Economic Review 107(4): 967-1004. D0I: 10.1257/ aer.107.4.967

Slack T. (2014). The social and commercial impact of sport, the role of sport management. European Sport Management Quarterly 14(5): 454-463. DOI: 10.1080/16184742.2014.974311

Sousa C.V., Aguiar S., Olher R.R., Cunha R., Nikolaidis P.T., Villiger E., Rosemann T., Knechtle B. (2021). What Is the Best Discipline to Predict Overall Triathlon Performance? An Analysis of Sprint, Olympic, Ironman ${ }^{\circledR} 70.3$, and Ironman ${ }^{\circledR}$ 140.6. Front. Physiol. 12:654552. DOI: 10.3389/ fphys.2021.654552

Sowell C.B., Mounts S. (2005). Ability, Age, and Performance. Journal of Sports Economics 6(1): 7897. DOI: $10.1177 / 1527002503260801$

Springman S. (2017). Triathlon - How a new multisport competition became an 0lympic and Paralympic Discipline. The 25th EASM Conference 5-8 September 2017. Book of Abstracts. Bern.

Tinley S. (2019). An enduring event: 20 years of one athlete's negotiation with pain at the Ironman Triathlon World Championships, pp. 55-70. In: The Suffering Body in Sport (Research in the Sociology of Sport, Vol. 12). Bingley: Emerald Publishing Limited. DOI: 10.1108/S1476285420190000012006

Van Bottenburg M. (2011). Why are the European and American sports worlds so different? Pathdependence in the European and American sports history. In book: Transformation of Modern Europe: States, Media and Markets 1950-2010. Routledge.

Volchik V.V., Oganesyan A.A. (2014). What is OIE needed for, if there is NIE? Terra Economicus 12(4): 79-90.

Volchik V.V. (2017). Narrative and institutional economics. Journal of Institutional Studies 9(4): 132-143. DOI: 10.17835/2076-6297.2017.9.4.132-143

Volchik V.V. (2020). Narratives and understanding of economic institutions. Terra Economicus 18(2): 49-69. DOI: 10.18522/2073-6606-2020-18-2-49-69

Wagner U. (2016). Agency constraints and possibilities: Athletes manoeuvring between the logics of community, market, profession and corporation in their quest for individual sponsorships. International Review for the Sociology of Sport 53(2): 213-233. D0I: 10.1177/1012690216643953

Waugh D., Dickson G., Phelps S. (2014). The impact of member disaffiliation on the internal legitimacy of a federated network. European Sport Management Quarterly 14(5): 538-555. D0I: 10.1080/16184742.2014.950306

Wicker P., Prinz J., Weimar D. (2013). Big spenders in a booming sport: consumption capital as a key driver of triathletes' sport-related expenditure. Managing Leisure 18(4): 286-299. D0I: 10.1080/13606719.2013.809190

Wu S.S.X., Peiffer J.J., Brisswalter J., Nosaka K., Lau W.Y., Abbiss C.R. (2015). Pacing strategies during the swim, cycle and run disciplines of sprint, Olympic and half-Ironman triathlons. European Journal of Applied Physiology 115(5): 1147-1154. D0I: 10.1007/s00421-014-3096-2 